\title{
Effects of ambient temperature and injection pressure on biodiesel ignition delay
}

\author{
Norrizam Jaat ${ }^{1, a}$, Amir Khalid ${ }^{1, b^{*}}$, Adiba Rhaodah Andsaler ${ }^{1}$, Azwan Sapit ${ }^{2}$, \\ Azahari Razali ${ }^{2}$ and Mariam Basharie ${ }^{3}$ \\ ${ }^{1}$ Automotive and Combustion Synergies Technology Group, Advanced Technology \\ Centre (ATC), Faculty of Engineering Technology, Universiti Tun Hussein Onn \\ Malaysia, EDU Hab Pagoh, 84600 Johor, Malaysia. \\ ${ }^{2}$ Combustion Research Group (CRG), \\ Centre for Energy and Industrial Environment Studies(CEIES), \\ Faculty of Mechanical and Manufacturing Engineering, \\ Universiti Tun Hussein Onn Malaysia, 86400 Parit Raja, Batu Pahat, Johor \\ ${ }^{3}$ Centre for Diploma Studies, Universiti Tun Hussein Onn Malaysia, \\ 86400 Parit Raja, Batu Pahat, Johor \\ Email: norrizam@uthm.edu.my ${ }^{\mathrm{a}}$; amirk@uthm.edu.my ${ }^{\mathrm{b}^{*}}$
}

\begin{abstract}
Biodiesels are promoted as alternative fuels due to their potential to reduce dependency on fossil fuels. The main problem in diesel combustion chamber design is to understand the importance of interaction phenomenon between fuel spray and surrounding gas prior to ignition. Rapid compression machine (RCM) is widely used to acquire experimental insights into fuel autoignition at conditions relevant to the current and future combustion technologies. An experimental study of the measurement of ignition delay characteristics of diesel and blended biodiesel fuels in the RCM was carried out. The objective of this study is to investigate the effects of various ambient temperature, $T_{i}$ and injection pressure, $\mathrm{P}_{\text {inj }}$ on ignition delay with different fuels used. This present study used the ignition delay of $5 \mathrm{vol} \%, 10 \mathrm{vol} \%$, and $15 \mathrm{vol} \%$ blending of palm oil methyl ester with a standard diesel as fuels in diesel engines called as B5, B10, and B15. The diesel fuel was blended with the biodiesel fuels at different fuel mixture blends. The injection pressure chosen was from $80 \mathrm{MPa}$ to $140 \mathrm{MPa}$ while an ambient temperature of RCM varied from $750 \mathrm{~K}$ to $950 \mathrm{~K}$. The results showed that for all tested fuels, the reduction in ignition delay increased with the increase in ambient temperature and injection pressure. The palm oil biodiesel had higher density, viscosity, and cetane number, facilitated the shortest ignition delay when compared to the diesel fuel under all ambient temperatures and injection pressures. The fuel oxygen content in the biodiesel fuel also played a greater role in decreasing the ignition delay.
\end{abstract}

Keywords: Rapid compression machine; ignition delay; ambient temperature; injection pressure.

\section{INTRODUCTION}

The rapid compression machine was applied in order to keep a wide observation region [1]. A number of experiments were conducted to study the mixture formation and combustion process performed in Rapid Compression Machine (RCM) [2-6]. RCM is an instrument designed to stimulate a single compression event of an engine cycle of internal 
combustion engine. The influence of the injection process inside the combustion chamber has to be considered in the analysis of combustion process. Most of the previous studies were conducted at high pressures and temperatures of air in the combustion chamber. The understanding of the interaction phenomenon between fuel spray and surrounding gas prior to ignition can be considered as a major problem while designing the diesel combustion chamber. During this period, combustible mixture caused spontaneous ignition since the air temperatures were above the fuel ignition point and occurred within delay period after fuel injected. Therefore, advanced combustion process, especially fuelair premixing needed to be designed and manufactured to comply with such legislated emissions. Basic studies in the RCM have been used to study the self-ignition characteristics of the fuel mixture under measured conditions [7-10]. The present study was conducted at the high ambient temperature inside the combustion chamber and injection pressure to analyse the ignition delay in the real diesel engine combustion like environment. The challenges in studying this regime include complex experimental observations to combine the physical-chemical processes that lead to a phenomenon like mixed auto-ignited combustion. Self-ignition was studied experimentally and the effects of ambient temperatures and injection pressures on the ignition delays of ordinary diesel fuels and its blends were considered. Combustion takes place in hot air in the real diesel engine. Hence, in the present study, the effects of high ambient temperatures and injection pressures of fuels developed in diesel engine combustion chamber on the ignition delay of fuels were also analysed. Studies with fuel injection into combustion chamber have shown that the ambient temperature and injection pressure of fuels are the most important parameters for a given fuel composition [11]. The combustion in diesel engines is mixed and the swirl is combined with high injection pressure to the inlet air to assist in the faster air-fuel mixing and better combustion. The high-pressure fuel injection induces a higher level of dispersion of the fuel with better atomisation and fuel-air mixing. The aim of the fuel injection process in a diesel engine is the preparation of a fuel-air mixing to achieve a clean and efficient combustion process [12].

In a diesel engine, ignition delay is a major factor in determining the rapid pressure rise in the initial burning stage and subsequent combustion stages. The ignition delay, which is defined as the time between the start of fuel injection and combustion also influences the combustion process strongly. The ignition delay in a diesel engine consists of the physical and chemical ignition delays $[13,14]$. Physical ignition delay corresponds to the mixture formation while chemical delay refers to the time necessary to get an exponential increase in the chemical reaction rate. Experimental strategies which leverage the strengths of RCM have been developed in recent years to make it particularly well suited for clarifying the physical-chemical processes. The physical processes involved are such as atomisation, penetration, entrainment, and vaporisation while the chemical processes are such as fuel decomposition and accumulation and oxidation [15]. In this study, an RCM equipped with a fuel injector was used to compare the combustion processes of the standard diesel and blended biodiesel fuels. The continuous rise in the cost of fossil fuels as well as environmental pollution has attracted investigations in the area of clean alternative fuels for improving the performance and emissions of internal combustion (IC) engines [16-23]. Biodiesel has been considered to be an alternative fuel to diesel in order to reduce the use of petroleum used. Biodiesel is a renewable energy source produced from vegetable oils and animal fats which can be used as a substitute for diesel fuels without making any changes to engine components [24-27]. The greatest weaknesses of using pure vegetable oils as fuels are their high viscosity and density. Transesterification process and other methods such as dilution, micro-emulsification, and 
pyrolysis have been identified as ways of reducing these two properties [28, 29]. Biodiesel has been recognised as one of the alternative fuels due to its biodegradability, high cetane number, no sulphur emissions, and low volatility. Biodiesel also offers many advantages including a decrease of $\mathrm{HC}, \mathrm{CO}$, and $\mathrm{NO}_{\mathrm{x}}$ gas emissions and many harmful pollutants. The biggest advantage that biodiesel has over diesel fuel is its environmental friendliness. Biodiesel burns similarly to petroleum diesel as it concerns regulated pollutants [30,31]. The test conditions generated in the RCM for this study were consistent with diesel engine conditions besides the ignition delay data describe the ignition behaviour of these fuels under realistic engine conditions. It allows the study of self-ignition of fuel and air mixing under easily controlled conditions and in a cleaner environment than the real engines. RCM is used to simulate a single compression stroke of an internal combustion engine without some of the complicated swirl bowl geometry, cycle-to-cycle variation, residual gas, and other complications associated with engine operating conditions. RCM is primarily used to measure ignition delay times as a function of temperature, pressure, and airfuel mixing ratio. In addition, RCM can be equipped with diagnostics such as pressure transducer to determine the temperature and pressure. RCM is also capable to determine the flow fields inside the reaction chamber and measure the concentrations of reactant, intermediate, and product species produced during combustion [32]. The objectives of this study are to investigate a systematic approach to testing fuel spray autoignition on $\mathrm{RCM}$ and using the approach to study the ignition characteristics of standard diesel and palm oil-derived biodiesel fuel sprays.

\section{METHODS AND MATERIALS}

\section{Experimental Setup}

The investigations on the combustion characteristics were conducted on a Rapid Compression Machine (RCM) by direct injection diesel spray with a variant injection pressure and ambient temperature. RCM has been designed for the purpose of chemical kinetics studies at elevated pressures and temperatures. RCM performs a single compression act of the engine. RCM in the present study was designed as a versatile tool which included the features of a well-defined core region, fast compression, ability to vary stroke and clearance, optical accessibility, and capability for special measurement. In this research, the influences of injection pressure and ambient temperature of constant volume chamber on ignition delay were determined. The experimental apparatus was divided into four systems such as rapid compression machine, common rail system, data acquisition systems and exhaust emission measurement systems. RCM was divided into three components which were the driver, cylinder liner, and combustion chamber. These experiments were conducted to develop an engine with better combustion by simulating the fuel injection in the RCM. Figure 1 shows a general schematic diagram of the device. A free-piston type rapid compression machine was used to simulate diesel combustion in a constant volume over a wide range of ambient temperature and pressure conditions similar to actual diesel engines. In addition, systems equipped with the pressure transducer for the measurement of ambient air pressures were developed inside the combustion chamber. Table 1 summarises operating parameters and fuel injection system including the specification of the nozzle used in the experiment.

In this study, commercially available standard diesel fuel was chosen as the baseline fuel. The diesel fuel was tested for the variation of ignition delay with the change in ambient temperature inside the combustion chamber and injection pressure for the injector. The biodiesel used in the experimental tests described in this paper was a methyl 
ester of palm oil. The diesel fuel was blended with the biodiesel fuels at different fuel mixture blends. Fuel blends containing $5 \mathrm{vol} \%, 10 \mathrm{vol} \%$, and $15 \mathrm{vol} \%$ of palm oil biodiesel in diesel oil tested were called B5, B10, and B15, respectively. The physical and chemical properties of the fuels are reported in Table 2. These blends were tested for variation of ignition delay with changes in ambient temperature and injection pressure inside the combustion chamber. The density of mixture blend would be different from baseline fuel due to the different blending percentage of diesel fuel. Therefore, the volume of the fuel mixture blend injected per stroke would also be similar to the diesel fuel by adjusting the duration of injection time.

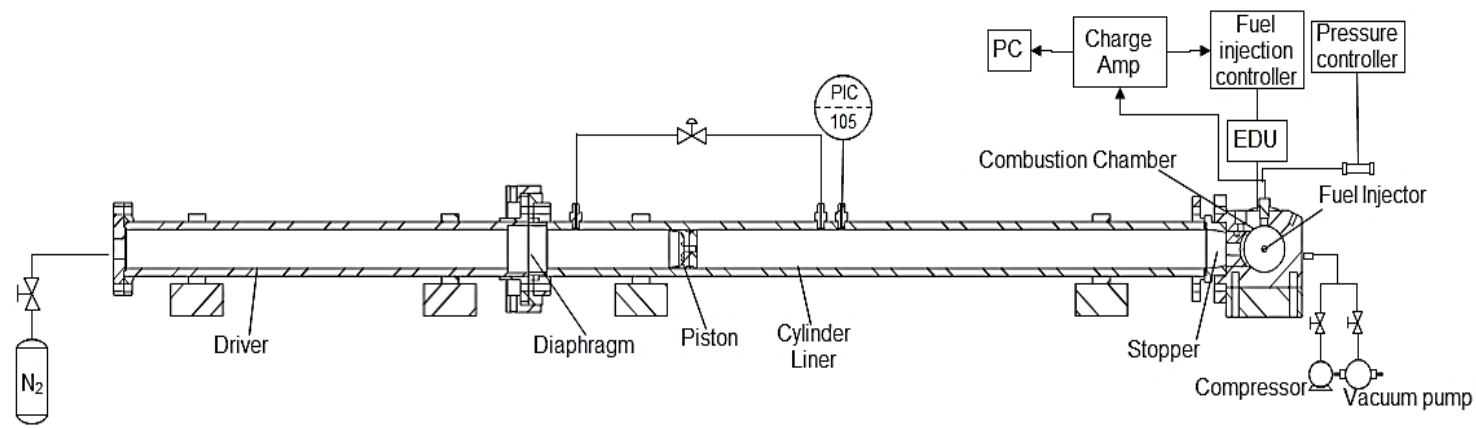

Figure 1. Schematic diagram of RCM.

Table 1. Experimental Specifications

\begin{tabular}{ll}
\hline \multicolumn{1}{c}{ Description } & \multicolumn{1}{c}{ Value and unit } \\
\hline Base swirl velocity, $r_{s}$ & $19 \mathrm{~m} / \mathrm{s}$ \\
Ambient temperature, $T_{i}$ & $750 \mathrm{~K}, 850 \mathrm{~K}, 950 \mathrm{~K}$ \\
Ambient pressure, $p_{i}$ & $4 \mathrm{MPa}\left(p_{c}=100 \mathrm{kPa}\right)$ \\
Ambient density, $\rho$ & $16.6 \mathrm{~kg} / \mathrm{m}^{3}\left(p_{c}=100 \mathrm{kPa}\right)$ \\
Nozzle diameter, $d_{n}$ & $0.129 \mathrm{~mm}$ \\
Injection pressure, $P_{i n j}$ & Low, $P_{i n j}=80-90 \mathrm{MPa}$ \\
& High, $P_{i n j}=130-140 \mathrm{MPa}$ \\
Injection system type & Electronic control \\
Oxygen concentration & $21 \%$ \\
\hline
\end{tabular}

Table 2. Fuel properties

\begin{tabular}{ccccc}
\hline Fuel type & $\begin{array}{c}\text { Density } \\
\left(\mathrm{g} / \mathrm{cm}^{3}\right)\end{array}$ & $\begin{array}{c}\text { Kinematic } \\
\text { viscosity }(\mathrm{cP})\end{array}$ & Flashpoint & $\begin{array}{c}\text { Cetane } \\
\text { number }\end{array}$ \\
\hline STD & 0.83374 & 2.9 & 80.0 & 55.7 \\
B5 & 0.83705 & 3.0 & 91.5 & 56.1 \\
B10 & 0.83766 & 3.01 & 92.0 & 56.3 \\
B15 & 0.84043 & 3.04 & 93.5 & 56.4 \\
\hline
\end{tabular}

The piston was driven by nitrogen gas at the constant pressure of $19 \mathrm{MPa}$, which was the pressure used for all of the experiments. The temperature of the linear cylinder and combustion chamber were also heated to requirement conditions. All equipment such as a piston, cylinder liner, combustion chamber, nitrogen gas, common rail system and diaphragms were prepared and connected. All connections were secured and sealed 
tightly to avoid leaking during the experiment. The common rail was switched on and the requirement pressures were set up to the fuel injector fixed at the opening of the combustion chamber. It is also important to make sure the controller, injector and Electronic Diesel Control were switched on. When fuel was injected into the combustion chamber with the assistance of fuel injection system, a pressure change took place inside the combustion chamber. The pressure change inside the combustion chamber was sensed by Kistler 601A, the piezoelectric pressure transducer sensor fitted in the combustion chamber head. Then, the signals were amplified with the sensitive charge from sensitive charger type Kistler 5018A before it was transmitted by data acquisition. PicoScope 3000 Series PC Oscilloscopes was used to measure voltages in the range of $-20 \mathrm{~V}$ to $+20 \mathrm{~V}$. The inputs were protected to $\pm 100 \mathrm{~V}$ ( $\pm 30 \mathrm{~V}$ for external trigger). PicoScope 3000 Series PC Oscilloscopes were connected directly to the ground of a computer through the interconnecting cable provided to minimise interference. Pico was connected directly while data was transferred to the computer for data analysis.

\section{RESULTS AND DISCUSSION}

\section{Effect of Ambient Temperature on Ignition Delay}

Blending was used in producing biodiesel fuels for analysing properties other than that diesel fuel are known for. Figure 2 compares the ignition delays between diesel, B5, B10, and $\mathrm{B} 15$ under the conditions of different ambient temperatures, $\mathrm{T}_{\mathrm{i}}$ and injection pressure, $\mathrm{P}_{\text {inj. }}$. The effects of injection pressure ranging from 80 to $140 \mathrm{MPa}$ on the ignition characteristics of fuel spray using direct injection system were investigated. It can be seen from the figure that the ignition delay for B5, B10, and B15 was lower than that of diesel fuel. It was noticed that the reduction in ignition delay of all test fuels increased with the increase in ambient temperature. The shortening in the ignition delay could be attributed to the enhanced mixing achieved at increasing ambient temperature. The reason may be because the increase in ambient temperature will increase the air pressure inside the combustion chamber as well as the density of the compressed air. This reduces the minimum auto-ignition temperature of the fuel because of the close contact of the molecules which thereby reduces the time of reaction when fuel is injected.

Furthermore, as investigated by [33], one of the factors that could affect ignition delay and subsequent combustion processes is the fuel cetane number. Biodiesel fuels have higher cetane number as presented in Table 2 and this could have facilitated its shorter ignition delay when compared to diesel. According to Knothe G [34], the higher cetane number for biodiesel than diesel reduced the size of premixed combustion and thus reducing the ignition delay. Another factor that could be responsible for the shortening of the ignition delay could also be the fuel oxygen content [35]. Compared to diesel, biodiesel fuel has a shorter ignition delay because of its high oxygen content. The maximum ignition delay was $1.15 \mathrm{~ms}$ for diesel (at $\mathrm{T}_{\mathrm{i}}=750 \mathrm{~K}$ and $\mathrm{P}_{\mathrm{inj}}=80 \mathrm{MPa}$ ) and lower ignition delay was $0.821 \mathrm{~ms}$ for B15 (at $T_{i}=950 \mathrm{~K}$ and $\left.P_{i n j}=140 \mathrm{MPa}\right)$. Generally, biodiesel contains a small percentage of diglycerides and has higher boiling points than diesel. However, the chemical reactions during the injection of biodiesel at a high ambient temperature resulted in the breakdown of the high-molecular-weight esters. These complex chemical reactions led to the formation of low molecular weight gases. Rapid gasification of this lighter oil in the fringe of the spray spread out the jet, and thus volatile combustion compound was ignited earlier resulting in a shorter ignition delay. On the other hand, the chemical properties; oxygenated fuel of biodiesel may promote the reaction to induce shorter ignition delay. If the delay time is too long, the accumulated 
air-fuel mixture available for the simultaneous explosion is large and thus causing rapid combustion with high pressure and temperature. Therefore, a decrease in the ignition delays was observed to increase in injection pressure in the study.

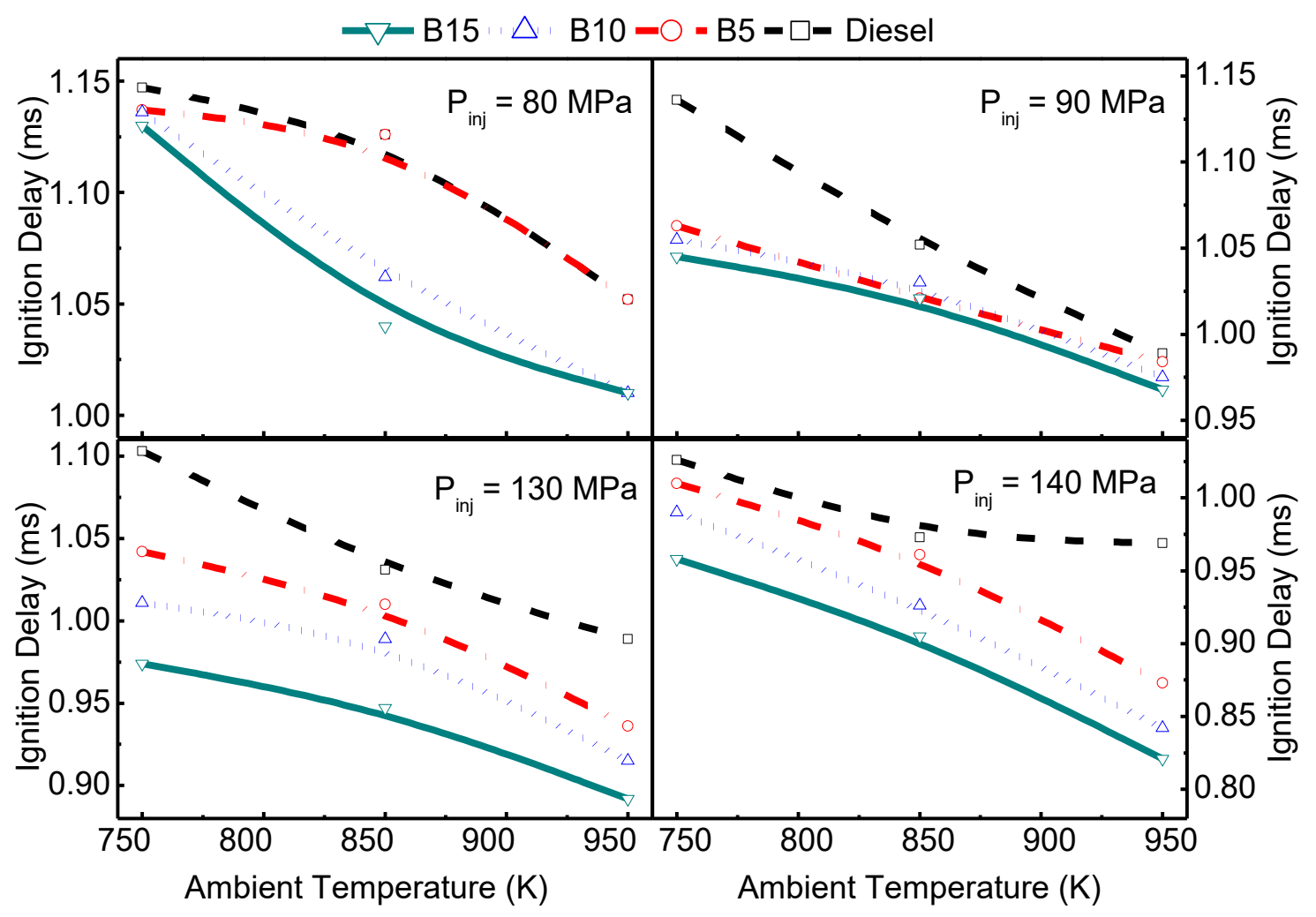

Figure 2. Effects of ambient temperature ignition delay of variant injection pressure.

\section{Effects of Injection Pressure on Ignition Delay}

Experiments were conducted on Rapid Compression Machine (RCM) for the measurement of ignition delays to generate the baseline characteristics. These baseline characteristics of standard diesel fuels were then compared to the blending characteristics of diesel with the biodiesel fuels from palm oil.-In this study, standard diesel fuel used was available in the market. All the blends and samples were prepared after careful filtration and accurately measured blending. Ignition delay is the period between the start of fuel injection into the combustion chamber and the start of combustion during the delay period; both the physical and chemical changes occurred at the same time. The variation of ignition delay period with different injection pressures for different fuels used is plotted in Figure 3. The graphs are separated for clarity. The observation results from the figure shows that the ignition delay trends for the different fuels were similar and ignition delays measured continuously decreased as the injection pressure increased. It occurred for all types of fuels used. Theoretically, ignition delay consists of two parts and is a sum of physical and chemical delays $[7,36]$. With the increase in the ambient temperature of the combustion chamber, the chemical delay of the impinging fuel spray decreased because the pre-flame chemical reactions during chemical delay were fast [37]. Thus, chemical delay decreased with an increase in ambient temperature. The other reason for the decrease in ignition delays with high ambient temperatures might be because the faster mixing rate resulted from faster fuel evaporation due to hot surface inside combustion chamber [38]. The impingement of the spray on the hot surface will affect the fuel 
evaporation and fuel-air mixing processes. Based on the investigation [39], the higher injection pressure distributed the larger amount of fuel-air premixing thus predominantly influenced the good spray atomisation and improvement of the combustible mixture.

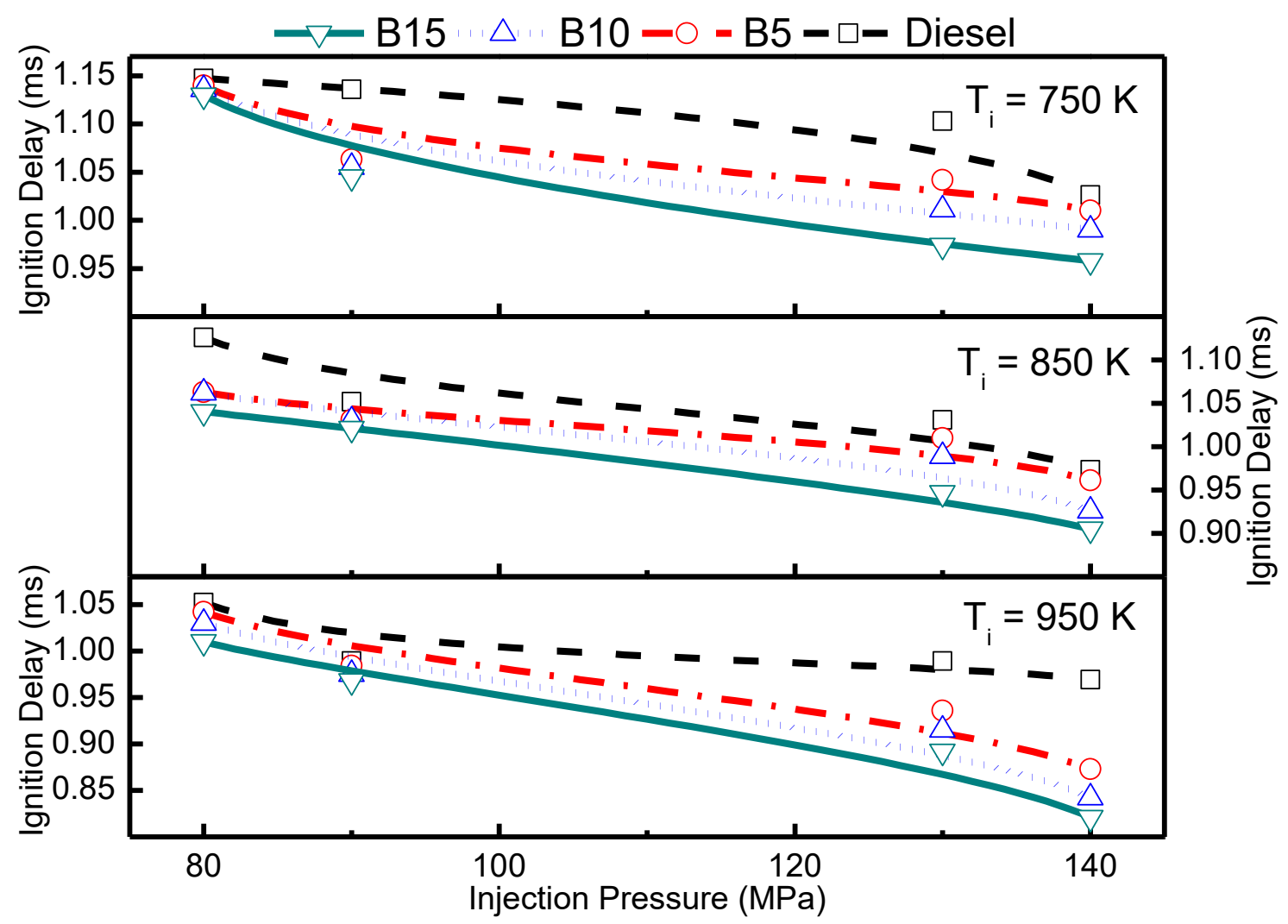

Figure 3. Effects of injection pressure on ignition delay of variant ambient temperature

\section{Effects of Ambient Temperature and Fuels on Ignition Delay}

The variation of ignition delay period with different ambient temperatures, $T_{i}$ and fuels for injection pressures, $\mathrm{P}_{\mathrm{inj}}$ is plotted in Figure 4. The figure presents the ignition delay of the biodiesel fuels and diesel fuel under the injection pressures of 80, 90, 130, and 140 MPa. The difference in ignition-delay trends in this study was believed to be caused by the difference in fuel properties. Results in the figure show that ignition delays decreased continuously with the increase in ambient temperature from $750 \mathrm{~K}$ to $950 \mathrm{~K}$ for all blends of biodiesel in diesel fuel. All of the biodiesel and diesel fuels generally exhibit a similar trend of ignition delay. Ignition delay largely decreased at low $\mathrm{T}_{\mathrm{i}}$ but slightly decreased at higher $T_{i}$ for lower $P_{i n j}$. The amount of evaporated fuel and chemical reaction rate in the combustion chamber increased as the ambient temperature increased. B5, B10, and $B 15$ fuels exhibited shorter ignition delay at higher $T_{i}$ compared to the diesel fuel. The reason for a decrease in ignition delays with higher ambient temperature may be due to the fast mixing rate resulting from faster fuel evaporation in higher temperature. The high temperature in the chamber indicated rapid evaporation to the injected fuels and shortenened ignition delay. It was noted that fuel with high density and viscosity gave the longer ignition with slow evaporation.

As the ambient temperature was higher, the surface of combustion chamber became hot. The impingement of fuel spray on hot surface affected the fuel evaporation and mixing processes. Similar effects were reported [40] that with an increase in wall temperatures, ignition delays decreased. Hence, the shortest ignition delays were obtained 
at higher ambient temperature while the longest ignition delays were obtained at a lower ambient temperature in the present study. This is an interesting aspect of auto-ignition diesel combustion according to the requirement of combustion in a diesel engine.

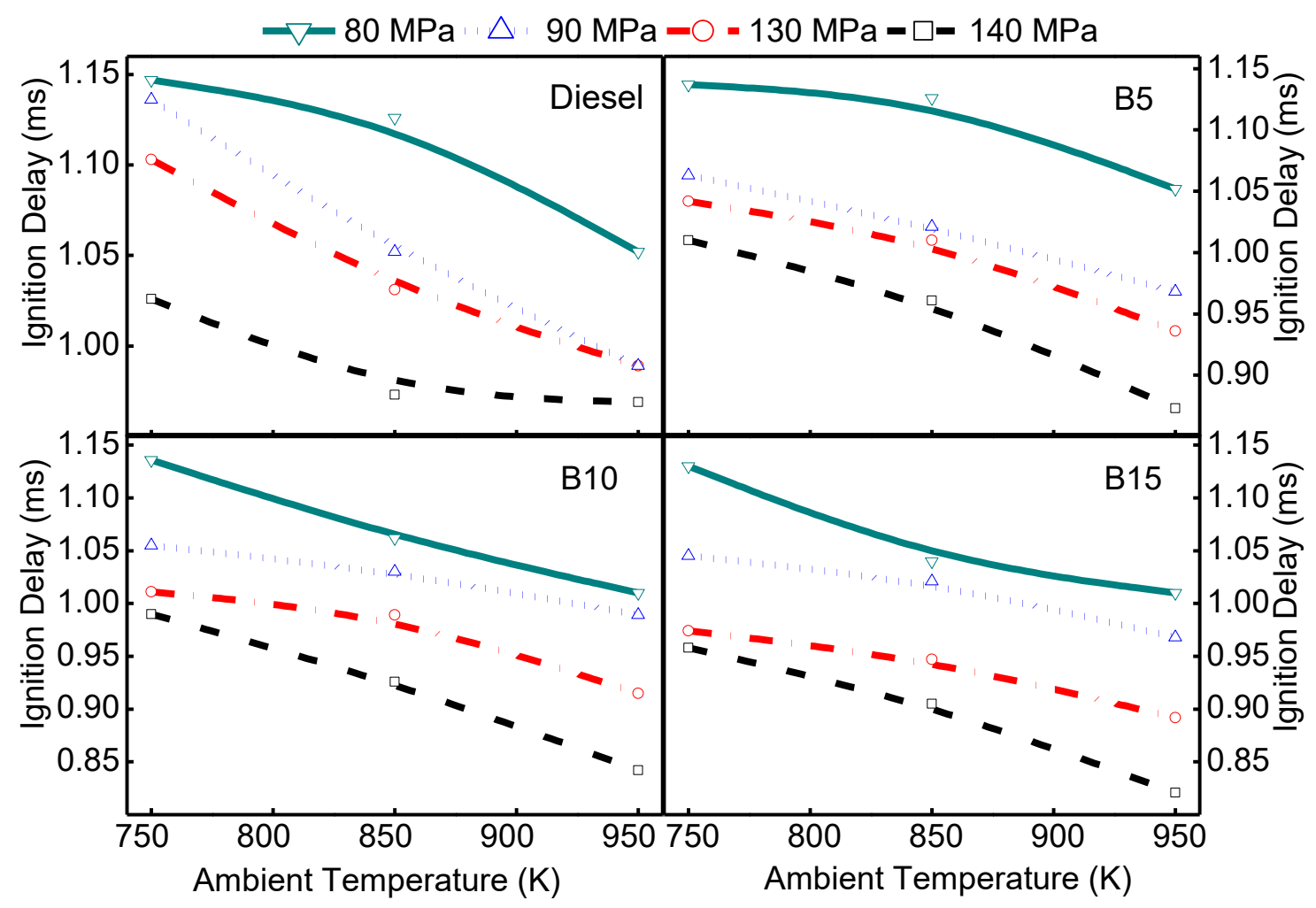

Figure 4. Effects of ambient temperature on ignition delay variant fuels

\section{CONCLUSIONS}

In this study, correlations were developed for predicting the ignition delay of tested fuels in a rapid compression machine. The ignition delay process of diesel and biodiesel fuels were fundamentally studied in this research under direct injection compression-ignition engine conditions. The ignition delay time between the time of injection and ignition depends on both physical processes for mixture formation and chemical processes leading to thermal decomposition and ignition. The temperature and pressure of the ambient air which related closely to these two processes were accordingly two of the major factors governing ignition delay. Fuel injection pressure and ambient temperature were also considered as important factors for determining ignition delay by way of the mixture formation. The physical properties of fuels such as viscosity, density, temperature, and pressure have various effects on ignition delay. The fuel cetane number representing the ignitability of fuels also has significant effects on ignition delay. The purpose of the present work was to experimentally study the effects of ambient temperature and injection pressure on ignition delay of standard diesel and palm oil biodiesel blended with diesel fuel (B5, B10, and B15) in the direct rapid compression machine. This research has proven the good overall behaviour of biodiesel in terms of ignition delay. The findings of this study can be summarised as follows: 
i) Ignition delay of diesel fuel and palm oil biodiesel blended with diesel was very sensitive to the variation of ambient temperature and injection pressure. A short ignition delay could be obtained by increasing $\mathrm{T}_{\mathrm{i}}$ and $\mathrm{P}_{\mathrm{inj}}$.

ii) Palm oil biodiesel had the shortest ignition delay which can be prolonged with the increasing biodiesel content in the blends. Biodiesel fuels also had a shorter ignition delay as a result of higher cetane number and oxygen content.

iii) Ignition delay decreased with the increase in ambient temperature and injection pressure for all tested fuels. Ambient temperature played an important role in determining the combustion process although higher temperature promoted the formation and oxidation.

iv) The evaporation and mixing process of every tested fuel was affected by the physical properties of fuel such as density, viscosity, and distillation temperature. The slow evaporation and mixing processes were predicted by the high viscosity and high-density of biodiesel fuels.

\section{ACKNOWLEDGEMENTS}

The authors would like to thank the Ministry of Higher Education, Malaysia for supporting this research under Fundamental Research Grant Scheme (FRGS) vot. 1466. This paper was partly sponsored by the Centre for Graduates Studies UTHM.

\section{REFERENCES}

[1] Shiozaki T, Nakajima H, Yokota H, Miyashita A. The Visualization and Its Analysis of Combustion Flame in a DI Diesel Engine. SAE Paper. No. 980141; 1998.

[2] Khalid A. Effect of ambient temperature and oxygen concentration on ignition and combustion process of diesel spray. Asian Journal of Scientific Research. 2013;6:434-44.

[3] Khalid A, Tomoaki Y, Takayuki M, Jun K, Yoshiyuki K. Analysis of relation between mixture formation during ignition delay period and burning process in diesel combustion. 15th Small Engine Technology Conference; 2009.

[4] Shundoh S, Kakegawa T, Tsujimura K. A study of direct injection diesel engine with $150 \mathrm{MPa}$ injection pressure. International Symposium C0M0DIA1990. p. 607-12.

[5] Shundoh S, Kakegawa T, Tsujimura K, Kobayashi S. The effect of injection parameters and swirl on diesel combustion with high pressure fuel injection. SAE Paper. No. 910489; 1991.

[6] Takahashi H, Tomaru K, Shiga S, Karasawa T, Kurabayashi T. Characteristics of diesel spray with unsteady and higher injection pressure using a rapid compression machine. SAE Paper. No. 910226; 1991.

[7] Teng H, McCandless JC, Schneyer JB. Compression ignition delay (physical+ chemical) of dimethyl ether-An alternative fuel for compression-ignition engines. SAE Paper No 2003-01-0759; 2003.

[8] Minetti R, Carlier M, Ribaucour M, Therssen E, Sochet L. A rapid compression machine investigation of oxidation and auto-ignition of n-heptane: measurements and modeling. Combustion and Flame. 1995;102:298-309.

[9] Finesso R, Spessa E. Ignition delay prediction of multiple injections in diesel engines. Fuel. 2014;119:170-90. 
[10] Ja'at M, Noh M, Norrizam M, Khalid A, Sapit A, Basharie SM, et al. Effects of temperature and ambient pressure on spray characteristics of biodiesel combustion. Appllied Mechanics and Materials.2015; 501-5.

[11] Khalid A, Andsaler AR, Manshoor B, Jaat N. Effect of high pressure on the flow characteristics of injector using computational fluid dynamics (CFD). ARPN Journal of Engineering and Applied Sciences. 2016;11:7503-6.

[12] Arrègle J, Pastor JV, Ruiz S. The influence of injection parameters on diesel spray characteristics. SAE Paper. No. 1999-01-0200; 1999.

[13] Rosseel E, Sierens R. The physical and the chemical part of the ignition delay in diesel engines. SAE Paper. No. 961123; 1996.

[14] De Toni A, Werler M, Hartmann R, Cancino L, Schießl R, Fikri M, et al. Ignition delay times of Jet A-1 fuel: Measurements in a high-pressure shock tube and a rapid compression machine. Proceedings of the Combustion Institute. 2017;36:3695-703.

[15] Corcione FE, Vaglieco BM, Valentino G. A Study of physical and chemical delay in a high swirl diesel system via multiwavelength extinction measurements. SAE Paper. No. 980502; 1998.

[16] Gonca G, Dobrucali E. Theoretical and experimental study on the performance of a diesel engine fueled with diesel-biodiesel blends. Renewable Energy. 2016;93:658-66.

[17] Datta A, Mandal BK. A comprehensive review of biodiesel as an alternative fuel for compression ignition engine. Renewable and Sustainable Energy Reviews. 2016;57:799-821.

[18] Tamilselvan P, Nallusamy N, Rajkumar S. A comprehensive review on performance, combustion and emission characteristics of biodiesel fuelled diesel engines. Renewable and Sustainable Energy Reviews. 2017;79:1134-59.

[19] Adam IK, A. Aziz AR, Yusup S. Determination of diesel engine performance fueled biodiesel (rubber seed/palm oil mixture) diesel blend. International Journal of Automotive and Mechanical Engineering. 2015;11:2675-85.

[20] Vashist D, Ahmad M. Statistical analysis of diesel engine performance for castor and jatropha biodiesel-blended fuel. International Journal of Automotive and Mechanical Engineering. 2014;10:2155-69.

[21] Hamada KI, Rahman MM, Ramasamy D, Noor MM, Kadirgama K. Numerical investigation of in-cylinder flow characteristics of hydrogen-fuelled internal combustion engine. Journal of Mechanical Engineering and Sciences. 2016;10:1782-802.

[22] Yasin MHM, Mamat R, Aziz A, Yusop AF, Ali MH. Investigation on combustion parameters of palm biodiesel operating with a diesel engine. Journal of Mechanical Engineering and Sciences. 2015;9:1714-26.

[23] Said NH, Ani FN, Said MFM. Review of the production of biodiesel from waste cooking oil using solid catalysts. Journal of Mechanical Engineering and Sciences. 2015;8:1302-11.

[24] Saifuddin N, Refal H, Kumaran P. Performance and emission characteristics of micro gas turbine engine fuelled with bioethanol-diesel-biodiesel blends. International Journal of Automotive and Mechanical Engineering. 2017;14:403049.

[25] Nayak SK, Mishra PC. Emission from a dual fuel operated diesel engine fuelled with Calophyllum Inophyllum biodiesel and producer gas. International Journal of Automotive and Mechanical Engineering. 2017;14:3954-69. 
[26] Shukri MR, Rahman MM, Ramasamy D, Kadirgama K. Artificial neural network optimization modeling on engine performance of diesel engine using biodiesel fuel. International Journal of Automotive and Mechanical Engineering. 2015;11:2332-47.

[27] Khalid A, Jaat N, Sapit A, Razali A, Manshoor B, Zaman I, et al. Performance and emissions characteristics of crude jatropha oil biodiesel blends in a diesel engine. International Journal of Automotive and Mechanical Engineering. 2015;11:2447-57.

[28] Yusuff AS, Adeniyi OD, Olutoye MA, Akpan UG. Performance and emission characteristics of diesel engine fuelled with waste frying oil derived biodieselpetroleum diesel blend. International Journal of Engineering Research in Africa: Trans Tech Publ; 2017. p. 100-11.

[29] Sundus F, Fazal M, Masjuki H. Tribology with biodiesel: A study on enhancing biodiesel stability and its fuel properties. Renewable and Sustainable Energy Reviews. 2017;70:399-412.

[30] Knothe G. Biodiesel and renewable diesel: A comparison. Progress in Energy and Combustion Science. 2010;36:364-73.

[31] Knothe G, Razon LF. Biodiesel fuels. Progress in Energy and Combustion Science. 2017;58:36-59.

[32] Goldsborough SS, Hochgreb S, Vanhove G, Wooldridge MS, Curran HJ, Sung CJ. Advances in rapid compression machine studies of low-and intermediatetemperature autoignition phenomena. Progress in Energy and Combustion Science. 2017;63:1-78.

[33] Oo CW, Shioji M, Nakao S, Dung NN, Reksowardojo I, Roces SA, et al. Ignition and combustion characteristics of various biodiesel fuels (BDFs). Fuel. 2015;158:279-87.

[34] Knothe G. Dependence of biodiesel fuel properties on the structure of fatty acid alkyl esters. Fuel Processing Technology. 2005;86:1059-70.

[35] Zannis TC, Hountalas DT, Kouremenos DA. Experimental investigation to specify the effect of oxygenated additive content and type on DI diesel engine performance and emissions. SAE 2004-01-0097; 2004.

[36] Shahabuddin M, Liaquat A, Masjuki H, Kalam M, Mofijur M. Ignition delay, combustion and emission characteristics of diesel engine fueled with biodiesel. Renewable and Sustainable Energy Reviews. 2013;21:623-32.

[37] Khalid A, Jaat N. Effects of ambient density on flow characteristics of biodiesel spray injection using computational fluid dynamics. ARPN Journal of Engineering and Applied Sciences. 2016;11:5499-505.

[38] Hwang J, Bae C, Gupta T. Application of waste cooking oil (WCO) biodiesel in a compression ignition engine. Fuel. 2016;176:20-31.

[39] Nursal RS, Khalid A, Tajuddin A, Syukri A. Performance and emissions characteristics of alternative biodiesel fuel on small diesel engine. ARPN Journal of Engineering and Applied Sciences. 2016;11:7424-30.

[40] Valipour A. Experimental combustion analysis of biodiesel fuel spray with hot surface ignition. IPASJ International Journal of Mechanical Engineering. 2014;2(1):1-14. 